\title{
Examining the Views of Preservice Science Teachers on Creating Concept Maps
}

\author{
Tuba Demirci ${ }^{1 *}$, Esra Kabataş Memiş² \\ ${ }^{1}$ Department of Science Education, Faculty of Education, Alanya Alaaddin Keykubat University, Alanya, Turkey, ${ }^{2}$ Department of Science Education, \\ Faculty of Education, Kastamonu University, Kastamonu, Turkey
}

*Corresponding Author: tuba.demirci@alanya.edu.tr

\section{ABSTRACT}

This study aimed to examine the views of preservice science teachers on concept map use in a General Chemistry II class. The study was conducted with 47 preservice science teachers. In the study, an interview form grounded on determining their views on concept maps and comprised of open-ended questions, was used as the data collection tool. In analysis of the data acquired, content analysis was performed. As a result of the analysis of the data, the preservice teachers expressed positive views on concept map use. They stated that it might contribute to their learning and increase the permanence of the knowledge learned. Furthermore, they reported that they liked creating concept maps and among the concept map types they usually chose to create hierarchical concept maps. Most of the preservice teachers stated that they had to know the subject related to the concept map very well to create concept maps more easily, otherwise they might have a difficulty in the concept map creation process and thus concept maps should generally be used after a lecture. In addition the preservice teachers stated that they intended to use concept maps in their teaching experience. As a result, before concept maps are used in teaching, it is recommended to inform students about the creation of concept maps, to use them for re-purpose in teaching activities, and to include activities containing concept maps in textbooks.

KEY WORDS: preservice science teacher; concept map; general chemistry

\section{INTRODUCTION}

In their study on "Learning How to Learn," Novak and Gowin (1984) introduced concept map use. Concept maps are based on concepts. In the literature a variety of concept definitions exist. Concept is defined as an abstract thought which is made meaningful by expressing its scope and content with a unit or thought (Demirel, 2003). Erden and Akman (1998) defined concept as a common name attributed to a group of events, opinions, and objects with similar characteristics. According to Senemoğlu (1997), concepts are mental tools enabling individuals to think. Concept maps were introduced within the scope of a research project conducted by Novak and his students aiming to teach concepts more easily in the area of science education in the 1970s, in association with meaningful learning (Novak and Gowin, 1984). Concept map is a method of establishing meaningful interconceptual relationships and propositions. According to Novak, concept maps should have a hierarchical order. Thematic concepts should be placed at the top of the map, while more special concepts should be placed at the bottom (Kaptan, 1998). Novak and Gowin suggested that concept maps would become more effective with active participation of students. It is because with such an activity, students have to establish a relationship between the opinions in their mind and the map they draw. As a consequence new knowledge is built by establishing an interconceptual relationship. In this respect concept, maps are also important for the constructivist approach. Table 1 shows definitions by experts regarding concept maps (Kılınç, 2007).

Conceptualization of knowledge is a product of meaningful learning (Ausubel, 1968). There are advanced differences between concepts and they can be arrayed from the most general to the most special. New knowledge is learned with cognitive order and hierarchy (Ausubel, 1968). This cognitive order has two important contributions. First, knowledge is organized with a discipline and methodology. Hierarchical order is important at this point. According to the order of priorities, downward array shows us the differences between the ongoing concepts. Second, the maps are visual, which enables us to see the connections easily and facilitates concept learning. Interconceptual relationships support meaningful and permanent learning (Sakiyo and Waziri, 2015; Marutirao and Patankar, 2016; Bulut, 2020). According to Kaptan (1998) concept maps comprise hierarchically arranged circles or boxes and connections between them. These connections show how a map maker synthesizes and integrates the concepts. Gaines and Shaw (1995) stated that intended purposes of concept maps are creativity, designing big texts, communication, learning, problem solving, and evaluation. In concept maps each concept is represented by circles (Hough et al., 2007). Circles are defined being connected by arrows which define interconceptual relationships (Kinchin et al., 2005; Chang and Chang, 2008). Concept maps also contain cross connections 


\begin{tabular}{|c|c|}
\hline Author & Definition \\
\hline Jonassen et al. (1997) & It is a map showing concepts and relationships. \\
\hline Grasha (1996) & It is a way of retention and effective learning. \\
\hline Maxwell (1996) & $\begin{array}{l}\text { It is a visual tool showing concepts and } \\
\text { expressing relationships. }\end{array}$ \\
\hline $\begin{array}{l}\text { Miles andand Huberman } \\
\text { (1994) }\end{array}$ & $\begin{array}{l}\text { It is a tool showing concepts and what kind of } \\
\text { hierarchy they are involved in. }\end{array}$ \\
\hline $\begin{array}{l}\text { Anderson-Inman and } \\
\text { Horney (1996) }\end{array}$ & $\begin{array}{l}\text { It is an image showing connections between } \\
\text { opinions and information. }\end{array}$ \\
\hline McAleese (1998) & It is a way including cognitive procedures. \\
\hline $\begin{array}{l}\text { Watters andand Zhou } \\
\text { (1999) }\end{array}$ & $\begin{array}{l}\text { It is an important strategy teaching multi- } \\
\text { information simultaneously and successfully. }\end{array}$ \\
\hline
\end{tabular}

(Jacobs-Lawson and Hershey, 2002). Cross connections may give information about how students associate the concepts with each other (Heinze-Fry and Novak, 1990; Novak, 1998).

Researchers classify concept maps in different ways on the basis of structural differences which emerge when drawing concept maps. Ebenezer and Haggerty (1999) divided concept maps into three groups: Hierarchical, non-hierarchical, and chain. Kinchin (2000) collected concept maps in three groups: Spoke, chain, and net. Vanides et al. (2005) collected concept maps in five groups: Linear, circular, spoke, tree, and network (Figure 1). Students with a simple information structure choose the linear structure when drawing concept maps, while students with more meaningful relationships in their cognitive structure choose the network structure when drawing concept maps (Vanides et al., 2005).

Hierarchical concept maps show the relationships of less comprehensive concepts under a comprehensive concept title within a structure ranging from general to special (Novak and Gowin, 1984). Novak and Gowin (1984) indicated hierarchy to be the most important structural property of concept maps because a cognitive structure is organized hierarchically and they discussed concept maps from a hierarchical point of view. Concept maps are a system which indicates interconceptual relationships with lines and includes concepts in the hierarchy (Kaptan, 1998).

Non-hierarchical concept maps which are also known as net, category, or spider concept maps, enable organizing interconceptual relationships in very different ways compared to hierarchical concept maps (Ebenezer and Haggerty, 1999). Not every subject content has a hierarchical structure (Shavelson, 1972; Ruiz-Primo and Shavelson, 1996). In subjects with several interconceptual relationships students choose the non-hierarchical structure when creating concept maps (Kaya and Ebenezer, 2003).

Examining the national and international literature; concept map applications are conducted in a wide range in different levels and subjects. Remarkable points in these studies are that concept maps affect the academic achievement and attitudes of students (Altınok and Açıkgöz, 2006; Ata and Adıgüzel, 2011; Oğraş and Bozkurt, 2011; Sakiyo and Waziri, 2015) and

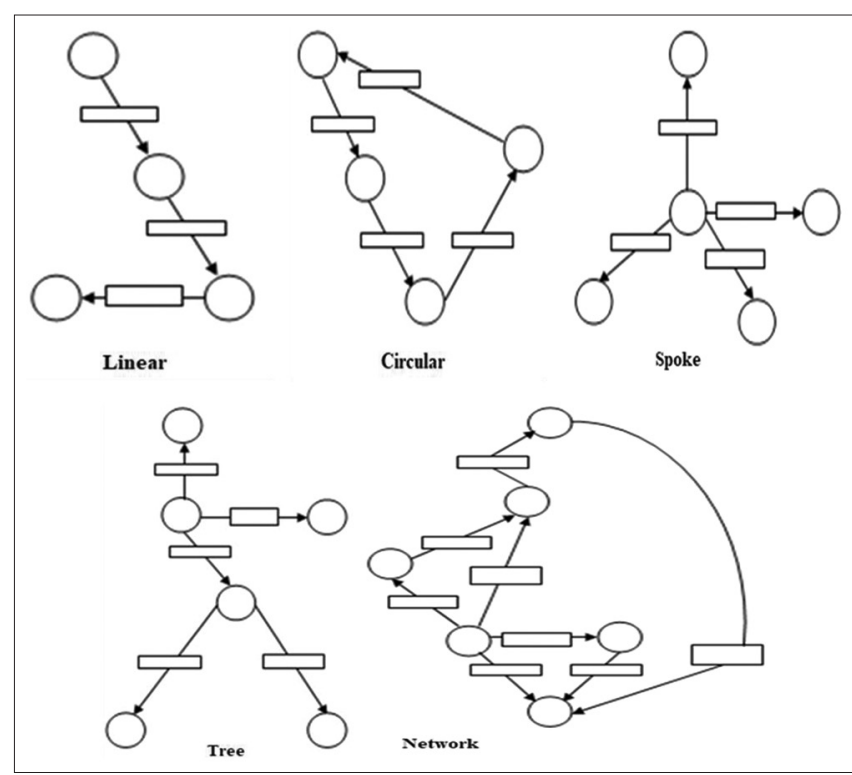

Figure 1: Examples of concept map figures (Vanides et al., 2005)

determination of misconceptions (Köse, 2007; Bulut, 2020), also they are used as an alternative means of evaluation (Kaya, 2003; Mwakapenda, 2003; Hsu and Hsieh, 2005; Gul and Boman, 2006; Müjdeci, 2009).

In some studies, concept maps were discussed as an activity created and used by teachers in lesson content (Çoban, 2007; Tuna, 2013; Biçer, 2017), whereas in other studies students were asked to create their own concept maps (Şahin, 2001; Erdem, 2008; İnel et al., 2011; Gürgen and Öztopalan, 2015; Oluk, 2016; Bulut, 2020). Studies examining students' views on the concept maps they create are limited in number. For that purpose, this study examined students' views on concept maps, which makes several contributions to learning. The study sought to enable concept maps to produce more effective outcomes and contribute to both students and the literature. Moreover, it is important to know the beliefs of preservice teachers regarding learning. In the future, preservice teachers will perform applications in line with their own beliefs in their class. If learning is defined as a conceptual structure occurring in mind, it is possible to state that this application to be performed will not only expand the conceptual network of students but also will also create a viewpoint for learning. Concept map applications show a parallelism with goals and applications included in the science curricula. In this context, the applications to be performed are believed to be an effective tool for bringing several abilities and attitudes in students. The applications will enable teachers who will raise the posterity, to be included in science lessons effectively. Choosing preservice teachers for the study group were crucial for raising the posterity who think, judge, and criticize and have critical thinking. The study aimed to determine the views of the $1^{\text {st }}$-year preservice teachers studying Science Teaching on the concept map creation process in line with their experiences. 


\section{METHODS}

As the study aimed to reveal students' views on concept map application, a descriptive method was used (Kaptan, 1977;

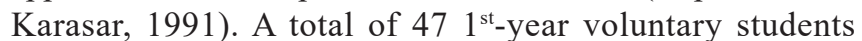
studying Science Teaching in Alanya Alaaddin Keykubat University's Department of Science Teaching and taking the General Chemistry II class in the spring term of the 2017-2018 academic year, were included in the study. Within the scope of the study it was important to enable the students to think and create concept maps on subjects in contents with different lengths and in different times (at the beginning, during, and at the end of the class). The General Chemistry II class was thought to be appropriate for creating a concept map, because it has the content which is both integrated and sectional in terms of subject and extent. From this perspective, the study group was determined as students taking the General Chemistry II lesson. The study was completed in 10 weeks. In this process, the students took their classes through traditional education. Within the scope of this course, eight subjects were taught: Preparation of Solutions with Certain Concentration Values, Dissolubility Phenomenon and Impact of Heat on Dissolubility, pH Concept and Acid-Base Indicators, Chemical Balance, Chemical Kinetics: Impact of Concentration and Heat on
Reaction Velocity, Chemical Bonds and Molecule Models, Chemistry and Energy, Electrochemistry. At the beginning of the term the students were informed of the study content, concept maps, and their types. Then an example concept map was created with each student on a non-course related subject to enable the students to comprehend the process and have a practice at creating a concept map. At the end of each of the eight subjects, the students were asked to create their personal concept maps within the scope of the subjects they learned. In addition, at the end of the term, they were asked to create a concept map comprising all subjects. Then their views were received to evaluate the process. As this study focused on students' views, the students were reminded that the content of their concept maps was not being evaluated. Figure 2 shows different examples from the concept maps created by the students.

\section{Collection of the Data}

As data collection tool, an interview form including nine openended questions which were determined by the researchers was administered to the students. The questions were aimed at determining their definition of concept maps, their views for the creation process, the difficulties they experience and determination of the source of these difficulties, and then

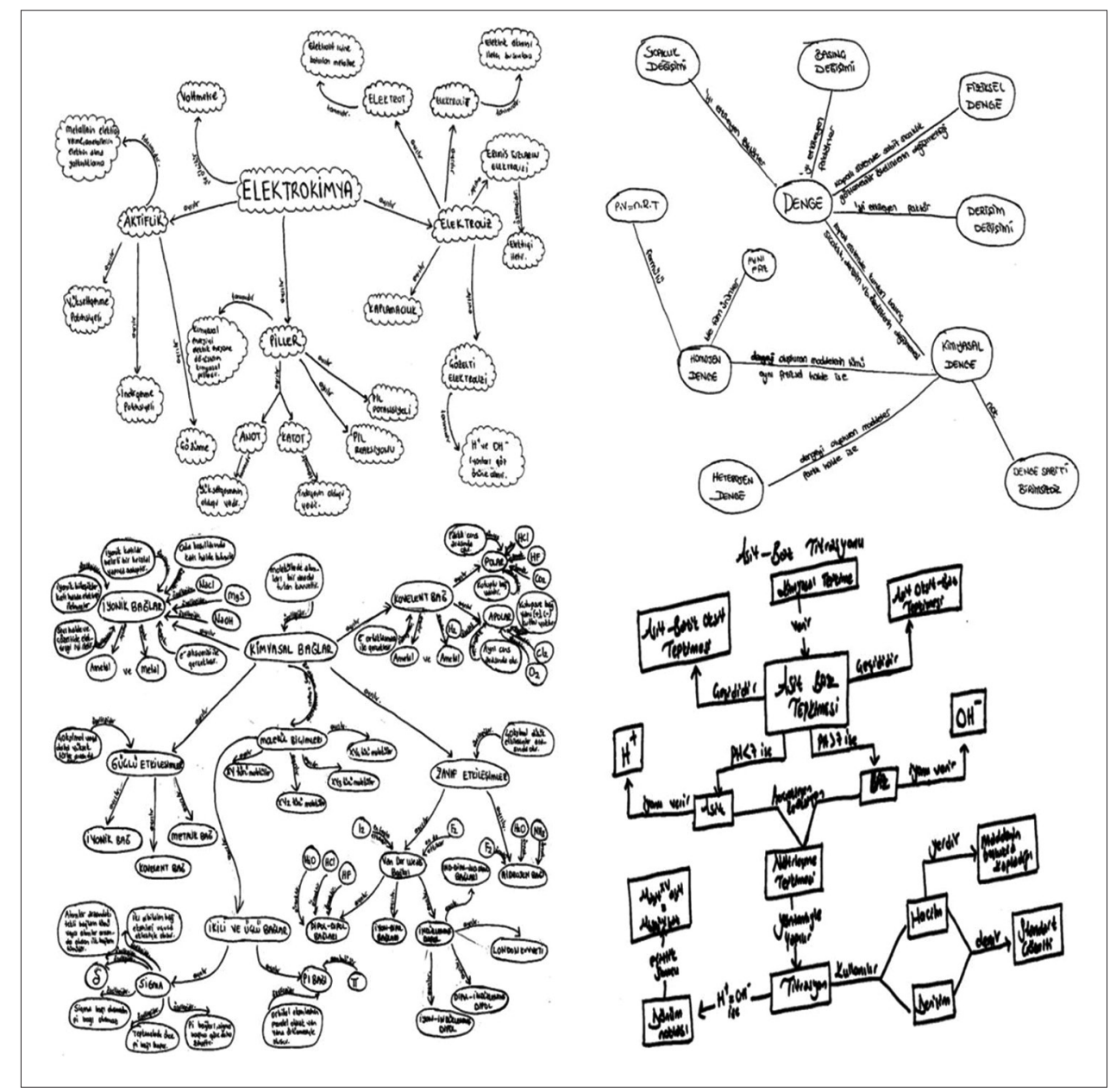

Figure 2: Examples of students' concept map 
whether they considered using the maps or not. In order to determine the thoughts of the students correctly, they were asked to consider their experiences. Also the questions specifically contained words such as "explain," "reason," and "justification." The questions were as follows:

1. Can you define concept map?

2. What do you think is the most important task of a concept map? Explain.

3. What kind of a concept map would you usually prefer to create? Can you explain why?

4. Do you like creating a concept map?

5. Have you had a difficulty creating a concept map? What are these difficulties?

6. What caused the greatest difficulty when creating a concept map?

7. What can be done to create concept maps more easily? Do you have a suggestion?

8. Concept maps can be used in different times of a lesson (beginning-process and end). When do you think they should be used? Give justification.

9. When you become a teacher, do you intend to use concept maps?

The students were given approximately one hour to answer the questions. Within this period they were asked to answer the questions individually. In addition, the students were particularly reminded that it was their views that were of interest to the researchers and that their answers were not subject to any evaluation.

\section{Analysis of the Data}

In analysis of the students' answers to the questions, the content analysis technique which is among qualitative data analysis techniques, was used. The students' answers to each question were evaluated individually. Content analysis of the students' views was performed by two researchers. As a result of the codings performed for each question, common codes were gathered and categories were created. In the content analysis similar data was gathered within the frame of specific concepts and themes and arranged and interpreted for readers to comprehend (Yıldırım and Şimşek, 2011). Analysis results were expressed with frequency.

\section{Findings and Interpretation}

In this section, the findings obtained as a result of data analysis were supported by student statements and shared. Tables 2-4 show the student views on concept maps and the frequency distribution of themes, categories, and codes revealed as a result of the content analysis. Tables 2-4 demonstrate the frequencies regarding categories and codes obtained from the questions addressed to the students. Each category is given in different titles.

\section{Findings Related to the Concept Map Knowledge}

To determine the concept map definitions of the students, the question "Can you define concept map" was addressed. Examining the answers to this question; the students made different definitions. They usually defined concept map as " $a$

\begin{tabular}{|c|c|c|c|}
\hline Theme & Category & Code & Frequency \\
\hline \multirow{26}{*}{$\begin{array}{l}\text { Concept } \\
\text { Map } \\
\text { Knowledge }\end{array}$} & \multirow{6}{*}{$\begin{array}{l}\text { Concept } \\
\text { map } \\
\text { definitions }\end{array}$} & $\begin{array}{l}\text { Diagram/map/chart showing the } \\
\text { relationship of concepts }\end{array}$ & 29 \\
\hline & & $\begin{array}{l}\text { Schematic table giving summary } \\
\text { info }\end{array}$ & 9 \\
\hline & & Way/means of learning & 6 \\
\hline & & $\begin{array}{l}\text { Means of organizing and } \\
\text { presenting information }\end{array}$ & 6 \\
\hline & & $\begin{array}{l}\text { Technic developing the visual } \\
\text { intelligence }\end{array}$ & 2 \\
\hline & & Means of evaluation & 2 \\
\hline & \multirow[t]{6}{*}{ Advantages } & Learning & 28 \\
\hline & & Permanence & 12 \\
\hline & & $\begin{array}{l}\text { Establishing a connection/ } \\
\text { providing ability }\end{array}$ & 9 \\
\hline & & Summarizing & 6 \\
\hline & & Clarifying the subject & 5 \\
\hline & & Developing imagination & 1 \\
\hline & \multirow{14}{*}{$\begin{array}{l}\text { Types of } \\
\text { concept } \\
\text { maps to be } \\
\text { used }\end{array}$} & Hierarchical (23) & \\
\hline & & Easier to create & 12 \\
\hline & & Comprehensible & 11 \\
\hline & & Seeing the subject integrity & 2 \\
\hline & & Concepts are clear/neat & 2 \\
\hline & & Spider (18) & \\
\hline & & $\begin{array}{l}\text { Easier to establish a } \\
\text { relationship }\end{array}$ & 10 \\
\hline & & Providing reinforcement & 2 \\
\hline & & Fun & 1 \\
\hline & & Chain (4) & \\
\hline & & Comprehensible & 2 \\
\hline & & $\begin{array}{l}\text { Easier to establish a } \\
\text { relationship/reinforcement/ } \\
\text { summarizing }\end{array}$ & 1 \\
\hline & & Net (2) & \\
\hline & & Fun/summarizing & 1 \\
\hline
\end{tabular}

diagram/map/chart showing the relationship of concepts." Considering that the most important point in creating a concept map is to express the relationship between the concepts specified; the students drew a particular attention to relationships in their definitions. For example, one of the students (S7) defined concept map as "a drawing associating the outline, titles, and basic points of a subject," while another student (S26) defined it as "the association of concepts to be known regarding a subject." A student coded S35 made the following definition "a map showing the relationship between the concepts of a subject." Following this concept association, the students usually defined concept map as thoughts summarizing these information. For example S6 defined it as "a map showing the relationship between the words giving information to summarize a subject," while S25 defined it as "summarizing the subjects by drawing a table with specific words." Indeed S47 stressed that this summarizing should be made at the end of a unit with the following definition "it is a process of schematization with fewer words at the end of a 


\begin{tabular}{llc}
\hline Table 3: Frequency distribution of categories and codes \\
regarding the "difficulty creating a concept map and its \\
source" theme
\end{tabular}

\begin{tabular}{|c|c|c|c|}
\hline \multirow{10}{*}{$\begin{array}{l}\text { Concept } \\
\text { Map Use }\end{array}$} & \multirow[t]{3}{*}{ Attitude } & Like & 22 \\
\hline & & Dislike & 11 \\
\hline & & Neutral & 13 \\
\hline & \multirow{4}{*}{$\begin{array}{l}\text { Time of creating a concept } \\
\text { map }\end{array}$} & End of the class & 20 \\
\hline & & Beginning of the class & 11 \\
\hline & & Process & 7 \\
\hline & & Not specified & 13 \\
\hline & \multirow{3}{*}{$\begin{array}{l}\text { Desire of using it when } \\
\text { teaching }\end{array}$} & Yes & 31 \\
\hline & & No & 8 \\
\hline & & Neutral & 6 \\
\hline
\end{tabular}

unit." Examining the definitions; noteworthy findings were that concept map was defined as a way/means of learning and information had to be presented in an organized way. The students stated that they had learned the subject via concept mapping and stressed that the method facilitated learning and helped them see the whole. S41 reflecting this thought made the following definition " $a$ structure facilitating learning and providing an integrity to the subject" and a student coded S24 defined it as a "map drawn for us to comprehend a subject." The definitions included "necessity of organizing and presenting concepts or relationships according to an order." For example S29 drew attention to the process with the statement "placing the terms complying with each other according to a specific order" and S38 with the statement "creating a map on concepts regarding any subject in a specific order." In addition the definitions included "developing the visual intelligence and a means of evaluation," although not much.

In the interview form the students were asked to address the question "What do you think is the most important task of a concept map? Explain." Examining the answers to this question; more than half of the students clearly drew attention to the concept of learning. Considering that the students answered the questions based on the processes they experienced; they mainly stressed that concept maps made the subjects they prepared more comprehensible and creating a concept map contributed to their learning. Moreover the students stressed that concept maps made the information permanent, provided the ability of establishing a connection and developed their imagination. Following are examples of student statements:

S11: Help us understand the subject very well.

S19: Help us understand the subject better and make it permanent.

S28: Teach us the meaning of concepts and their connections with other concepts.

S35: Help us comprehend the concepts schematically.

S40: Establish a connection between the old and new information.

S2: Summarize the subject and make it easier to understand.

The students were informed of the types of each concept map and were told how to construct each. The students were free to create any concept map. In the interview form the students were asked the question "What kind of a concept map would you usually prefer to create? Can you explain why." Examining the answers, the students chose hierarchical, spider, chain, and net concept maps from most to least. The students choosing the hierarchical concept map stated that it was easier to create, had a better comprehensibility level, and it helped them see the concepts clearly and the subject as a whole. The students choosing the spider concept map mainly stressed that it facilitated establishing relationships.

\section{Findings Regarding the Difficulty Creating a Concept Map and its Source}

In the interview form the students were asked whether they had a difficulty creating a concept map or not and 31 students clearly stated that they had a difficulty in the process. Fourteen students indicated that they had no difficulty, while two students did not answer the question. Moreover, two students who indicated that they had no difficulty, specified a subject in the category of difficult subjects under this theme. Although this condition shows the inconsistency of the answer given, the codings were performed in line with student statements. 
The students associated the difficulty with inadequate field information (15), difficulty establishing an interconceptual relationship (14), failure of determining a concept (4), shortness of subject in determining a concept (4), and lack of experience (2). Furthermore, the students were asked to write down the subjects they had a difficulty creating a concept map. In their answers the students stated that they had the greatest difficulty in titration (23), which was followed by indicator (8), stoichiometry (6), dissolubility (3), solution (2), crystallization (1), substance (1), and acid-base (1) subjects, respectively. Five students stated that they usually had a difficulty in chemistry subjects without specifying the subject, while five students indicated that they had a difficulty creating a concept map.

Furthermore, the students were asked to offer suggestions regarding how to overcome any difficulty. In this context most of the students (27) stated that they could overcome the problem as long as they mastered the subject related to the concept map. In addition, the students stressed that determining the main concepts forming the basis of concept maps, avoiding to create a concept map frequently and in every subject and creating a draft in the first place, would overcome the difficulty creating a concept. Following are examples of student statements regarding these thoughts:

S2: I think it is better not to do it often. However, it would be much better to do it when the concepts are abundant and the subject is long enough. I think concept maps should not be created in every subject.

S8: They could be created more easily when relevant concepts are learned and analyzed better.

S18: To study...

S19: Before creating a concept map, one should master the relevant subject.

S27: It is better to do it at the end of a unit rather than frequently. It is because I have a difficulty associating the concepts I learn in every class with the general concept.

S36: First of all we should understand the subject very well. Then we should do little research. Finally we should imagine it in our mind and begin to do it.

S41: We should begin to create a concept map after doing extensive research.

S43: We can prevent difficulties by overcoming our deficiencies and trying to master the subject.

\section{Findings Regarding Concept Map Use}

Regarding the concept map creation process, the students first addressed the question "Do you like creating a concept map?" Nearly half of the students (22) stated that they liked creating a concept map, while eleven students stated that they did not. On the other hand, thirteen students remained neutral. The neutral students particularly used statements such as "not always, depends on the subject."

Another question combined in this theme was related to the time of creating a concept map. In this title some of the students specified multiple time zones for using concept maps. The time zones specified by these students were coded individually. Twenty students stated that it was appropriate to use concept maps at the end of the class and stressed that the maps could be used as an evaluation tool at the end of the subject. Similarly 11 students specifying the beginning of the class for using concept maps stated that the maps could be used for measuring the readiness level of students. Seven students indicated that the maps should be used in the process to understand the lesson better. However, thirteen students did not express any opinion.

To evaluate whether the concept map creation process would affect their future or not, the students were addressed the question "When you become a teacher, do you intend to use concept maps?" Analyzing their answers, most of the students (31) stated that they intended to use concept maps. Very few students (8) avoided making a definite statement, while six of them remained neutral. The students who did not intend to use concept maps, stated that they had a great difficulty creating a concept map, failed especially in finding a concept and lacked field information and information about creating a concept map in general. This being the case the students' difficulty also affected their choices. A remarkable finding was that most of the students intended to use concept maps when teaching, although they had a difficulty.

\section{DISCUSSION AND CONCLUSION}

This study aimed to determine the views of $1^{\text {st }}$-year preservice science teachers on concept map use. These preservice teachers defined concept maps by stressing the importance of interconceptual relationship and using the expressions of diagram $/ \mathrm{map} / \mathrm{chart}$. The literature has similar definitions of concept maps. Senemoğlu (1997) defined concept map as a two-dimensional chart showing the concepts in a person's mind and the relationships between these concepts. Kaya (2003) defined it as a two-dimensional chart showing concepts and interconceptual relationships diagrammatically and evaluating the conceptual comprehension of students. Liu defined it as a hierarchical two-dimensional visual tool presenting interconceptual relationships. In the process the preservice teachers created concept maps many times. These definitions make us think that the preservice teachers coded concept maps in their mind correctly. In addition, according to their experiences based on the concept map creation process, they stated that creating a concept map had several advantages such as helping to learn, providing permanence, helping to establish a connection, providing summarization, and making a subject comprehensible. Several studies have shown that concept maps are effective on learning and the permanence of knowledge (Jegede et al., 1990; Briscoe and LaMaster, 1991; Hay and Kinchin, 2006; İnel et al., 2011; Gürgen and Öztopalan, 2015).

Concept maps can be created in four different ways: Hierarchical, spider, chain, and net (Vanides et al., 2005). Net, category, or spider concept maps enable arranging interconceptual relationships in different ways compared to hierarchical concept maps (Ebenezer and Haggerty, 1999). In 
this study, the students stated that they usually chose to use hierarchical concept maps in the concept map creation process. The reason why these students chose the hierarchical structure was because they arrayed the interconceptual relationships in their mind from the most general to the most special (Novak and Gowin, 1984). According to Novak concept maps should have a hierarchical order. Kaşl1 et al. (2001) suggested that they could be showed by being divided into subunits. According to Ausubel learning occurs from top to bottom or in a deductive way (Kılınç, 2007). He stated that he used a spider concept map besides the hierarchical concept map when creating several concept maps. Spider maps can be particularly used in organizing basic opinions. In such maps the key concept is in the center and there are special concepts around it (Çoban, 2007). On the other hand, students choose spider maps because they are easier to create (Bahar, 2001). Concept maps created by students may have a different structure. What matters is to establish the right connections between the concepts (Novak and Gowin, 1984). The structure of a concept map may vary according to the subject (Derbentseva et al., 2007).

In the interview form the preservice teachers stated that concept map creation was a useful process. However, they stressed that they usually had difficulty in the process mainly because they lacked background knowledge. The reason for preservice teachers having difficulty in creating concept maps and associating the concepts is that they learnt the subjects only in the class and never used different resources and materials to learn outside the class. Furthermore, they felt inadequate when creating a concept map. Students can determine the parts where they have difficulty understanding the subject themselves when creating concept maps (Ebenezer, 1992; Nakhleh, 1994; Kaya and Ebenezer, 2003). The literature contains studies suggesting that students have difficulty creating their own concept maps, especially drawing a concept map and establishing interconceptual relationship. These studies stress that establishing interconceptual connections or cross connections depends on knowing the subject. Indeed studies suggest that students with inadequate knowledge on the subject also have difficulty determining the concepts (Novak and Canas, 2006; Derbentseva et al., 2007; Tzeng, 2009; Çakmak, 2010; Çetin and Taşar, 2015, Gürgen and Öztopalan, 2015).

These preservice teachers stated that they had the greatest difficulty in titration when creating a concept map. This may be because the titration subject is taught via direct expression prior to the laboratory application lesson and thus students are not able to fully internalize the subject. Students had difficulty defining acid-base concepts such as " $\mathrm{pH}$, neutralization, strong acids and bases" (Sheppard, 2006). Similarly, Çağlar (2007) suggests that the "Acid-Base Titration" subject in the General Chemistry lessons in university contains several physical events and chemical reactions that students have difficulty imagining. Nakiboğlu and Nakiboğlu (2016) examined chemistry students' comprehension of basic concepts related to titration using the Vee diagram which was completed during the laboratory class and concluded that the students were inadequate in defining concepts like titration and indicator.

Concept maps relating to the presentation of structural information can actually be considered a strong tool for learning-teaching and evaluation of the conceptual comprehension of students in a specific subject area (Beyerbach and Smith, 1990; Markham et al., 1994; Kinchin, 2000). This indicates the multidimensional use of concept maps in the learning-teaching process. In this study, the preservice teachers often specified that concept maps could be used at the end of the class. Novak and Gowin (1984) suggest that concept maps present a visual summary regarding what have been learned after completing a learning task. Some of the preservice teachers stated that concept maps could be used at the beginning of the class. The literature contains studies suggesting that concept maps are crucial for revealing the prior knowledge and comprehension of students especially at the beginning of the class (Snead and Young, 2003; Liu, 2004).

Most of the preservice teachers stated that they intended to use concept maps in their teaching experience despite all the difficulties faced especially the students who remained neutral stressed expressions between being useful and having difficulties, which was interesting. In their study, Şaşmaz and Tatar (2009) found that preservice teachers intended to use concept maps in their teaching experience. For students to use concept maps, it is necessary to raise their awareness. Furthermore, it is necessary to encourage students to use other materials similar to concept maps, which may provide them with meaningful and permanent learning. It is necessary to encourage teachers to use alternative evaluation technics like concept maps, instead of traditional exams. Specific difficulties are encountered creating concept maps. Unless students have understood the interconceptual relationships well enough, they may create wrong concept maps. Thus, it can be recommended that educational applications be performed for students to create concept maps and prepare activities more consciously.

\section{REFERENCES}

Altınok, H., \& Açıkgöz, K. (2006). Effects of cooperative and individual concept mapping on attitude toward science. Hacettepe University Journal of Education, 30, 21-29.

Anderson-Inman, L., \& Horney, M. (1996). Computer-based concept mapping: Enhancing literacy with tools for visual thinking. Journal of Adolescent and Adult Literacy, 40(4), 302-306.

Ata, N., \& Adigüzel, T. (2011). Stages technique in concept mapping: Its effect on students' concept-map creating level and achievement in math education. University of Gaziantep Journal of Social Science, 10(2), 803-823.

Ausubel, D.P. (1968). Educational Psychology. United States: Holt, Rinehart and Winston.

Bahar, M. (2001). Use of Concept Maps in Biology Education. Abant izzet Baysal University Journal of Faculty of Education, 1(1), 25-40.

Beyerbach, B.A., \& Smith, J.M. (1990). Using a competerized concept mapping program to assess preservice teachers' thinking abaut effective teaching. Journal of Research in Science Teaching, 27(10), 961-971.

Biçer, N. (2017). The Impact of Using Concept Maps on Academic Achievement in The SubLearned Area of Polygons in $7^{\text {th }}$ Grade Maths and Intervews of Student. (Master Dissertation, Gazi University, Ankara).

Briscoe, C., \& LaMaster, S.U. (1991). Meaningful learning in college 
biology through concept mapping. The American Biology Teacher, 53(4), 214-219.

Bulut, Ö.L. (2020). Determination of Misconceptions of Chemistry Teacher Candidates about Solution and Solubility with Concept Maps Technique. (Master Dissertation, Gazi University, Ankara).

Chang, S.L., \& Chang, Y. (2008). Using online concept mapping with peer learning to enhance concept application. The Quarterly Review of Distance Education, 9(1), 17-27.

Çağlar, S. (2007). Technology Assisted Instruction of Titrations Subject University. (Master Dissertation, Balıkesir University, Turkey).

Çakmak, M. (2010). An examination of concept maps created by prospective teachers on teacher roles. Procedia Social and Behavional Sciences, 2, 2464-2468.

Çetin, İ.N., \& Taşar, M.F. (2015). Using concept maps to determine pre service science teachers views about the nature of science. Journal of Theory and Practice in Education, 11(4), 1185-1206.

Çoban, B. (2007). Use of concept maps as a teaching technique in the lecture athletics. Firat University Journal of Social Science, 17(1), 161-171.

Demirel, Ö. (2003). Dictionary of Education. $2^{\text {nd }}$ ed. India: Pegem Academy.

Derbentseva, N., Safayeni, F., \& Cañas, A. (2007). Concept maps: Experiments on dynamic thinking. Journal of Research in Science Teaching, 44(3), 448-465.

Ebenezer, J.V., \& Haggerty, M.S. (1999). Becoming a Secondary School Science Teacher. United States: Merill.

Ebenezer, J.V. (1992). Making chemistry learning more meaningful. Journal of Chemical Education, 69, 464-467.

Erdem, E. (2008). Examining students' concept mapping and problemsolving beliefs in general chemistry course. Hacettepe University Journal of Education, 35, 111-122.

Erden, M., \& Akman, Y. (1998). Education Psychology (Development, Learning, Teaching). United States: Arkadaş Yayınevi.

Gaines, B.R., \& Shaw, M.L.G. (1995). Concept maps as hypermedia components. International Journal of Human Computer Studies, 43(3), 323-361.

Grasha, A.F. (1996). Teaching with Style. Pittsburgh: Alliance Publishers.

Gul, R., \& Boman, J. (2006). Concept mapping: A strategy for teaching and evaluation in nursing education. Nurse Education in Practice, 6, 199-206.

Gürgen, E.T., \& Öztopalan, R. (2015). Collaborative concept mapping in music history lesson. İnönü University Journal of Art and Design, 5(12), $37-46$.

Hay, D.M., \& Kinchin, I.M. (2006). Using concept maps to reveal conceptual typologies. Education and Training, 48, 79-83.

Heinze-Fry, J.A., \& Novak, J.D. (1990). Concept mapping brings longterm movement toward meaningful learning. Science Education, 74(4), 461-472.

Hough, S., O'Rode, N., Terman, N., \& Weissglass, J. (2007). Using conceptmaps to assess change in teachers' understandings of algebra: A respectful approach. Journal of Mathematics Teacher Education, $10(1), 23-41$.

Hsu, L., \& Hsieh, S. (2005). Concept maps as an assessment tool in a nursing course. Journal of Professional Nursing, 21(3), 141-149.

İnel, D., Evrekli, E., Deniş, H., \& Balım, A.G. (2011). Views on concept maps of science teacher candidates. Uşak Journal of Social Science, 4(2), 239-266

Jacobs-Lawson, J.M., \& Hershey, D.A. (2002). Concept maps as an assessment tool in psychology courses. Teaching of Psychology, 29(1), 25-29.

Jegede, O.J., Alaiyemola, F.F., \& Okebukola, P.A.O. (1990). The effect of concept mapping on students' anxiety and achievement in biology. Journal of Research in Science Teaching, 27(10), 951-960.

Jonassen, D.H., Reeves, T.C., Hong, N., Harvey, D., \& Peters, K. (1997). Concept mapping as cognitive learning and assessment tools. Journal of Interactive Learning Research, 8(4), 289-308.

Kaptan, F. (1998). The use of concept map technique in science education. Hacettepe University Journal of Education, 14, 95-99.

Kaptan, S. (1977). Scientific Research Techniques. Tamil Nadu: Tek Işık Matbaas1.

Karasar, N. (1991). Scientific Research Methods: Terms, Principles and Techniques. Turkey: Nobel Yayınevi.
Kaşl1, A.F., Aytaç, V., \& Erdur, G. (2001). Concept mapping. Ege Journal of Education, 1, 127-136.

Kaya, O.N. (2003). Concept maps in science education. Pamukkale University Journal of Education Faculty, 1(13), 70-79.

Kaya, O.N., \& Ebenezer, J.V. (2003). A Longitudinal Study of the Effects of Concept Mapping and Vee Diagramming on Senior University Students' Achievement, Attitudes and Perceptions in Science Laboratory. Philadelphia, PA: Paper presented at the annual conference of the National Association for Research in Science Teaching (NARST, USA).

Kılınç, A. (2007). Using concept maps as a teaching strategy. Yüzüncü Yll University Journal of Education Faculty, 4(2), 21-48.

Kinchin, I.M. (2000). Concept mapping in biology. Journal of Biological Education, 34(2), 61-68.

Kinchin, I.M., De-Leij, F.A.A., \& Hay, D.B. (2005). The evolution of acollaborative concept mapping activity for undergraduate microbiology students. Journal of Further and Higher Education, 29(1), 1-14.

Köse, S. (2007). The effects of concept mapping instruction on overcoming $9^{\text {th }}$ grade students' misconceptions about diffusion and osmosis. Journal of Baltic Science Education, 6(2), 16-25.

Liu, X. (2004). Using concept mapping for assessing and promoting relational conceptual change in science. Science Education, 88(3), 373-396.

Markham, K., Mintzes, J., \& Jones, M.G. (1994). The concept map as research and evaluation tool: Further evidence of validity. Journal of Research in Science Teaching, 31, 91-101.

Marutirao, G.A., \& Patankar, P.S. (2016). Effect of concept maps on academic achievement in the subject biology among the higher secondary level school students. International Interdisciplinary Research Journal, 6, 79-85.

Maxwell, J.A. (1996). Qualitative Research Design: An Interactive Approach. United States: Sage Publications.

McAleese, R. (1998). Coming to Know: The Role of the Concept Map Mirror, Assistant, master? Eric No: ED429968. United Kingdom: Eric.

Miles, M.B., \& Huberman, A.M. (1994). Qualitative Data Analysis: An Expanded Sourcebook. $2^{\text {nd }}$ ed. United States: Sage Publications.

Müjdeci, S. (2009). The Usage of Concept Maps as an Alternative Measurement Evaluation Instrument in the Mathematics Education. (Master Dissertation, Marmara University, Institution of Educational Science, İstanbul)

Mwakapenda, W. (2003). Concept mapping and context in mathematics education. İn: Rogerson, A., (Ed.), Proceedings of The $6^{\text {th }}$ International Conference of The Mathematics Education Into The 21 $1^{\text {st }}$ Century Project. Berlin, Germany: Freie Universität Berlin. pp. 193-198.

Nakhleh, M.B. (1994). Chemical education research in laboratory environment. Journal of Chemical Education, 71, 201-205.

Nakiboğlu, N., \& Nakiboğlu, C. (2016). An investigation of universty chemistry students'understanding of precipitation titrations and related concepts thorough vee-diagrams. The Eurasia Proceedings of Educational and Social Sciences, 4, 564-567.

Novak, J.D. (1998). Learning, Creating, and Using Knowledge: Concept Maps as Facilitative Tools in Schools and Corporations. United States: Lawrence Erlbaum and Associates.

Novak, J.D., \& Canas, A.L. (2006). The Theory Underlying Concept Maps and How to Construct and Use Them. Technical Report IHMC Cmap. Tools 2006-1. Pensacola: Florida İnstitute for Human and Machine Cognition

Novak, J.D., \& Gowin, D.B. (1984). Learning How to Learn. Cambridge: Cambridge University Press.

Oğraş, A., \& Bozkurt, A. (2011). The effect of using concept mapping and v-diagrams in primary school 7 mathematics course upon student success. Gümüşhane University Electronic Journal of The Institute of Social, 2(3), 1-13.

Oluk, N.T. (2016). The Comparision of Different Concept Mapping Tasks in Chemistry Education. (Doctoral Dissertation, Gazi University, Ankara).

Ruiz-Primo, M.A., \& Shavelson, R.J. (1996). Problems and issues in the concept maps in science assessment. Journal of Research in Science Teaching, 33, 569-600.

Sakiyo, J., \& Waziri, K. (2015). Concept mapping strategy: An effective tool for improving students' academic achievement in biology. Journal of Education in Science, Environment and Health (JESEH), 1(1), 56-62. 
Senemoğlu, N. (1997). Development Learning and Teaching (From Theory to Practice). Turkey: Gazi Kitabevi Yayınları.

Shavelson, R.J. (1972). Some aspects of the correspondence between content structure and cognitive structure in physics instruction. Journal of Educational Psychology, 63, 225-234.

Sheppard, K. (2006). High school students' understanding of titrations and related acid-base phenomena. Chemistry Education Research and Practice, 7(1), 32-45.

Snead, D., \& Young, B. (2003). Using concept mapping to aid african american students' understanding in middle grade science. Journal of Negro Education, 72(3), 333-343.

Şahin, F. (2001). Concept map of teacher candidates and application opinions about. Pamukkale University Journal of Education Faculty, 10, $12-25$.

Şaşmaz, Ö.F., \& Tatar N. (2009). Examination of the relationship between the knowledge level and opnions of pre-service teachers about concept maps. In: Taşar, M.F., \& Çakmakcı, G., (Eds.), Contemporary Science
Education Research: Pre-service and In-service Teacher Education. Ankara, Turkey: Pegem Akademi. pp. 33-42.

Tuna, F. (2013). The Impact of Concept Maps on Students' Academic Achievement in Geography Education and Students' Perceptions of Implementation. Mehmet Akif Ersoy University Journal of Education Faculty, 13(25), 182-197.

Tzeng, J. (2009). The impact of general and specific performance and selfefficacy on learning with computer-based concept mapping. Computers in Human Behavior, 25, 989-999.

Vanides, J., Yin, Y., Tomita, M., \& Ruiz-Primo, M.A. (2005). Using concept maps in the science classroom. Science Scope, 28(8), 27-31.

Watters, C., \& Zhou, W. (1999). Interactive lateral map: Using the web for collaborative analysis. WebNet Journal Internet Technologies, Applications and Issues, 1(3), 34-39.

Yıldırım, A., \& Şimşek, H. (2011). Qualitative Research Methods in the Social Sciences. Greece: Seçkin Yayıncılık. 